DOI: 10.32089/WBH.phw.2019.2(268).0007

orcid.org/0000-0002-1268-0432

\title{
Kilka uwag do książki Roberta Litwińskiego pt. Kordian Józef Zamorski „granatowy” generat
}

Biografistyka jest jedną z najtrudniejszych ${ }^{1}$, a być może i najtrudniejszą historiograficzną formą. Wynika to przede wszystkim z kwestii metodologicznych i źródłowych. Historyk przygotowujący biografię musi nie tylko bardzo dokładnie zgłębić życiorys bohatera swojej książki, ale również powinien dość mocno poznać czasy, w których tenże człowiek żył. Sytuacja taka sprawia, że autor musi wczytać się w ogromny stos literatury dotyczący różnych historycznych okresów. Co więcej, gdy bohater biografii działał na różnych polach i pracował w kilku instytucjach, historyk zobowiązany jest do odszukania i poznania całej gamy istotnych dokumentów, dzięki którym będzie mógł zobrazować życie interesującego go człowieka. Ważne jest zatem, aby poszukiwania i kwerendy źródłowe przeprowadzić w wielu instytucjach, jak choćby Archiwum Akt Nowych, ale także w tych, do których dotarcie jest niekiedy utrudnione. Zaliczyć do nich można np. archiwa szkolne, uczelniane, zakładowe, a także prywatne. Ponadto badacz nie tylko musi wykazać, czym opisywany człowiek zajmował się w poszczególnych okresach swojego życia. Zgodnie z obowiązującymi we współczesnej historiografii standardami powinien spróbować zajrzeć w „duszę" swojego bohatera i spróbować np. odpowiedzieć, czym motywowane były jego życiowe wybory, jakie opinie posiadał nt. różnych wydarzeń itd.

Mniej więcej takiego trudu podjął się Robert Litwiński, który postanowił przybliżyć czytelnikom biografię postaci ciekawej, ale dość słabo znanej, tj. gen. Kordiana Józefa Zamorskiego. Autor specjalizujący się w dziejach różnego rodzaju instytucji policyjnych działających na obszarze Polski w XX w., a także w polityce wewnętrznej II Rzeczypospolitej ${ }^{2}$ wyłamał się zatem ze schematu narzuconego, zapewne nieświadomie, przez grupę polskich historyków badających dzieje Polski pierwszej połowy XX stulecia,

1 https://www.polskieradio.pl/8/3664/Artykul/1210511,Profesor-Antoni-Dudek-napisalem -biografie-potwora-bo-mnie-zainteresowal (dostęp 25 II 2019 r.).

2 https://www.umcs.pl/pl/addres-book-employee,1583,pl.html (dostęp 25 II 2019 r.). 
którzy zajmowali się głównie poznawaniem życiorysów wysokich rangą polskich oficerów, którzy większość swojego dorosłego życia poświęcili służbie wojskowej lub publicznej. Dzięki pracy wykonanej przez Litwińskiego czytelnik może skorzystać z okazji i poznać biografię ostatniego przed wybuchem II wojny światowej komendanta polskiej Policji Państwowej (PP).

Omawiana książka składa się ze Wstępu, czterech zasadniczych rozdziałów, a także Zakończenia, Wykazu źródet i opracowań, Wykazu skrótów i Indeksu osobowego. Przyjęty przez autora układ opracowania ma formę chronologiczno-problemową, co w tym przypadku jest rozwiązaniem najbardziej odpowiednim. Litwiński stara się bowiem w przejrzystym wywodzie pokazać życie i działalność „granatowego generała”, jak sam określa Kordiana Zamorskiego.

Pierwszy rozdział został zatytułowany Ku Polsce niepodległej. Autor podzielił go na cztery mniejsze podrozdziały - Dzieciństwo $i$ lata szkolne, Początki działalności niepodległościowej, W Krakowie, Wielka Wojna. Litwiński zobrazował w nich młodość Zamorskiego od momentu urodzenia w 1890 r. do zakończenia I wojny światowej. $Z$ tego rozdziału czytelnik dowie się m.in.: skąd i z jakiej rodziny Zamorski pochodził, gdzie się kształcił, jak wyglądała jego niepodległościowa działalność czy też w jaki sposób potoczyły się jego losy w okresie pierwszego globalnego konfliktu zbrojnego.

Rozdział drugi zatytułowany $W$ armii II Rzeczypospolitej został podzielony na następujące podrozdziały: Walka o granice, Lata spokoju, W Sztabie Głównym Wojska Polskiego, O sytuacji politycznej w kraju. Cezurę czasową tego fragmentu wyznaczają lata 1918-1935. Pod koniec 1918 r. Zamorski wstąpił bowiem w szeregi odradzającego się WP, a na początku 1935 r. został przeniesiony $\mathrm{z}$ armii $\mathrm{w}$ tzw. stan nieczynny. $\mathrm{W}$ rozdziale drugim opisana została działalność generała w polskiej armii, jak choćby szefostwo sztabu Dowództwa Okręgu Korpusu nr III w Grodnie, szefostwo Oddziału I Sztabu Generalnego (Głównego) (SG) czy wreszcie jego aktywność na stanowisku II zastępcy szefa SG WP. Ponadto w ostatnim podrozdziale tego fragmentu autor przedstawił spostrzeżenia Zamorskiego na politykę ogólną, personalną i techniczną, prowadzoną przez sanację $\mathrm{w}$ WP $\mathrm{w}$ latach trzydziestych XX w.

Kolejny rozdział został zatytułowany Na czele policji. Na jego treść składają się trzy podrozdziały - Komendant Główny Policji Państwowej, Nowi podwładni i Ku profesjonalizacji korpusu. Litwiński przybliżył w nich nie tylko realną działalność Zamorskiego, ale także pewne idee, reformy i założenia, które Zamorski wprowadzał lub zamierzał wprowadzić do kierowanej przez niego instytucji.

Książkę zamyka rozdział czwarty, który nosi tytuł Na uchodźstwie i emigracji. W czterech podrozdziałach - Wrzesień 1939, W Rumunii, Na Bliskim 
Wschodzie, W Wielkiej Brytanii pokazano zawiłe losy „granatowego generała” od momentu wybuchu II wojny światowej, poprzez internowanie w Rumunii, pobyt na Bliskim Wschodzie, wyjazd do Anglii, aż do jego śmierci, która nastąpiła w $1983 \mathrm{r}$.

Kolejnym pozytywem omawianej publikacji, prócz przejrzystości wywodu, jest także przedstawiona na końcu książki bibliografia. Autor dotarł do bardzo wielu dokumentów i źródeł, które rozproszone były w 19 archiwach. Wśród instytucji, które Litwiński odwiedził i przeprowadził w nich kwerendę, znajdują się m.in. Archiwum Akademii Sztuk Pięknych w Krakowie, Archiwum Akt Nowych w Warszawie, Biblioteka Zakładu Narodowego im. Ossolińskich we Wrocławiu, Centralne Archiwum wojskowe Wojskowego Biura Historycznego w Warszawie-Rembertowie, a także polskie komórki archiwalne działające za granicą, takie jak choćby Instytut Józefa Piłsudskiego w Nowym Jorku czy też Instytut Polski i Muzeum im. gen. Sikorskiego w Londynie. Ponadto Litwiński skorzystał z dokumentacji Rosyjskiego Państwowego Archiwum Wojskowego w Moskwie oraz pracował na źródłach przechowywanych $\mathrm{w}$ instytucjach, takich jak np. archiwa państwowe ulokowane m.in. w Bydgoszczy, Katowicach, Lublinie czy Warszawie oraz w warszawskim Muzeum Policji.

Dodatkowo autor w swojej pracy wykorzystał całą masę ważnych dokumentów już wydrukowanych, dotarł do kilkudziesięciu źródeł pamiętnikarskich i wspomnieniowych, przejrzał bogatą $\mathrm{w}$ informacje prasę epoki i skorzystał z kilkuset opracowań. Ilość wykorzystanych artykułów i książek byłaby zapewne dużo większa, gdyby w przypisach biograficznych Litwiński podawał tytuły prac, $\mathrm{z}$ których korzystał przy przedstawianiu danej postaci. Ponadto lubelski historyk nie skorzystał z kilku ważnych opracowań dotyczących różnych opisywanych w książce wydarzeń. Próżno w niej szukać np. klasycznej monografii dotyczącej I wojny światowej autorstwa Jana Dąbrowskiego ${ }^{3}$ czy też monumentalnej pracy pod redakcją Piotra Staweckiego pt. Zarys z dziejów wojskowości polskiej w latach 1864-19394. Braki te w żaden sposób nie umniejszają jednak trudu i wysiłku, które autor włożył w pracę nad biografią Zamorskiego.

Ten przywołany powyżej stos dokumentów i literatury Litwiński wykorzystał do przygotowania pierwszej, w zasadzie kompletnej, biografii generała. Autor zapełnił zatem lukę w polskiej historiografii. Do tej pory niezbyt wielu interesowało się postacią Zamorskiego. Dlaczego się tak działo? Na to pytanie trudno znaleźć odpowiedź. Pełnił on przecież ważne, aczkolwiek nie pierwszoplanowe funkcje w strukturach wojskowych armii

3 J. Dąbrowski, Wielka wojna 1914-1918. Na podstawie najnowszych źródeł, cz. 1-4, Poznań 2000-2001.

4 Zarys dziejów wojskowości polskiej w latach 1864-1939, red. P. Stawecki, Warszawa 1990. 
II Rzeczypospolitej, a także był ostatnim przed wybuchem II wojny światowej komendantem głównym PP. Oczywiście ranga człowieka nie powinna tylko i wyłącznie decydować o przygotowaniu jego biografii ${ }^{5}$. Niemniej jest to często element najistotniejszy. W takim wypadku należy zatem pamiętać, że kierowana przez generała PP odgrywała istotną rolę w utrzymaniu porządku publicznego w przedwojennej Polsce, a na jej barkach spoczywała choćby walka z komunistami działającymi na obszarze II Rzeczypospolitej. $\mathrm{W}$ tej sytuacji już jakiś czas temu należało przygotować biografię człowieka, który przez kilka lat miał spory wpływ na jej funkcjonowanie.

Z przytoczonego powyżej powodu biografia Zamorskiego jest bez wątpienia książką ważną i nowatorską. Niemniej autor już na samym wstępie postawił przed sobą zadanie trudne i odważne zarazem. Na s. 12, cytując Aleksandra Gieysztora, napisał: „Biografistyka stawia dziś sobie niemałe wymagania: od pokazywania bohatera w powieści w kontekście społecznym i kolein jego losów w jego zbiorowości, aż do czerpania z nam współczesnej psychologii, a przy tej pomocy do prób rozumienia psychiki”. Za takie ujęcie swoich zamierzeń autorowi wypada tylko przyklasnąć. Czym innym są jednak założenia, a czym innym ich realizacja.

Biografia Kordiana Zamorskiego to przede wszystkim praca, w której autor starał się pieczołowicie i bardzo uważnie rekonstruować poszczególne fragmenty życia bohatera swojej książki. O tym, że była to robota bardzo mozolna i drobiazgowa, świadczyć może wspomniany powyżej fragment recenzji dotyczący bibliografii omawianej książki. Ponadto Zamorski był osobowością interesującą, o dość dużych horyzontach myślowych, a w swoim życiu piastował niejedno ważne stanowisko. Nie było zatem łatwo odtworzyć jego życiorys.

Litwińskiemu udało się zbudować mocny szkielet swojej książki. Czytelnik bez większych problemów dowie się z niej wielu istotnych informacji o poszczególnych okresach życia Kordiana Zamorskiego. Autor zrekonstruował m.in., jak wyglądały początki pracy konspiracyjnej bohatera książki, a także jak układały się mu studia na krakowskiej Akademii Sztuk Pięknych. Zamorski zapowiadał się zresztą na niezłego artystę. Z młodzieńczych marzeń nic jednak nie wyszło, a generał oddawał się swojej pasji w chwilach wolnych od służby. Jak zauważył Litwiński, powstawały wówczas przyzwoite dzieła sztuki, jak choćby portret żony, namalowany w 1936 r., którego reprodukcja została umieszczona na końcu książki.

W kolejnych fragmentach opracowania autor bardzo skrupulatnie odtwarzał kolejne elementy bogatego życiorysu Zamorskiego. Litwiński

V. L. Zaszkilniak, Trudności biograficznego badania albo jak za drzewami zobaczyć las? [w:] Biografistyka we współczesnych badaniach historycznych. Teoria i praktyka, red. J. Kolbuszewska, R. Stobiecki, Łódź 2017, s. 28-29. 
poprowadził zatem swój wywód przez działania I wojny światowej, wojny polsko-ukraińskiej i wojny polsko-bolszewickiej. Następnie opisał działalność generała na różnych dowódczych stanowiskach w WP. Kolejnych kilkadziesiąt stron poświęcił jego służbie w Sztabie Głównym, gdzie Zamorski piastował funkcję szefa Oddziału I, a także II zastępcy szefa SG. $\mathrm{Z}$ fragmentów tych dowiemy się, jakie były jego ówczesne kompetencje oraz zapatrywania i opinie. Dzięki spisywanym przez lata przez Zamorskiego dziennikom autor mógł odtworzyć, z jakimi problemami generał się wówczas borykał. Jak się okazuje, generał miał dość krytyczny stosunek do wielu osób z najbliższego otoczenia Marszałka Józefa Piłsudskiego. Zresztą do tego ostatniego, od pewnego momentu, nastawiony był co najmniej polemicznie. Autor potrafił to sprawnie wykorzystać i w wielu fragmentach swojej książki pozwolił „mówić” Zamorskiemu, przytaczając jego wypowiedzi. Dzięki nim czytelnik dowie się, że pomimo zadeklarowanej wszem i wobec lojalności wysokich oficerów WP wobec Piłsudskiego znajdowali się tacy, jak choćby Zamorski, którzy potrafili dość krytycznie patrzeć na jego postać. Nie każda decyzja ówczesnego Generalnego Inspektora Sił Zbrojnych podobała się generałowi i on skrupulatnie to odnotowywał.

Po przeczytaniu książki odniosłem również wrażenie, że Litwiński miał spory szacunek i sympatię do bohatera swojej publikacji. Jednocześnie dzięki poznaniu tej biografii mogę stwierdzić, że ja takim uczuciem do Zamorskiego nie zapałałem. Uważam go bowiem za postać dość dwuznaczną. $\mathrm{Z}$ jednej strony był człowiekiem bardzo bystrym, rozmiłowanym w sztuce, o wyraźnym, literackim talencie, który wykorzystał np. do pisania swojego dziennika. Był również sprawnym żołnierzem i organizatorem, który swoje obowiązki starał się wykonywać skrupulatnie i sumiennie. Z drugiej strony, szczególnie po 1935 r., wpadał w coraz większe rozżalenie, które w późniejszym okresie zamieniło się chyba w malkontenctwo. Wynikało to w dużej mierze $z$ tego, że czynniki decyzyjne państwa polskiego odsunęły go od piastowania ważnych funkcji, a w późniejszym okresie nie zamierzały wykorzystać jego talentów i umiejętności. W rezultacie o różne rzeczy oskarżał m.in. Piłsudskiego, marszałka Edwarda Śmigłego-Rydza, ale również premiera Władysława Sikorskiego i jego najbliższe otoczenie oraz innych urzędników i wojskowych, a później również środowiska emigracyjne. W pewnym momencie nie było chyba grupy decyzyjnej, do której Zamorski nie miałby jakiś pretensji. Książka Litwińskiego doskonale ten problem pokazuje.

Niemniej zgodnie z jedną z głównych zasad historycznego warsztatu autor nie traktuje źródeł wybiórczo i potrafi krytycznie spojrzeć na bohatera swojego opracowania. Do tego posłużyły mu opinie osób, które Zamorskiego znały i różnie się o nim wypowiadały. W publikacji nie ma ich 
zbyt wielu, jednak autor umieścił je w omawianej publikacji, w konkretnych kontekstach i sytuacjach.

Gdy w styczniu 1935 r. generał został odwołany ze Sztabu Głównego, oddano go do dyspozycji ministra spraw wewnętrznych. Ten zaś skierował go na stanowisko komendanta głównego PP. Temu fragmentowi życiorysu Zamorskiego autor poświęcił 78 stron swojej publikacji. Opisał w nich m.in. przyczyny, które spowodowały, iż objął to stanowisko, a także jego poglądy, zresztą dość krytyczne, na działalność i funkcjonowanie PP. Litwiński przybliżył również, jak wyglądała jego ówczesna zawodowa aktywność, kim byli jego najbliżsi współpracownicy, a także jakie zmiany starał się w policji wprowadzać i co z nich konkretnie wynikało. Opisał także jego kontakty z policją niemiecką oraz znajomość z osławionym szefem SS Heinrichem Himmlerem. Niestety w tym fragmencie zabrakło mi kilku elementów dotyczących realnego funkcjonowania PP. Chciałbym np. przeczytać o największych sukcesach i porażkach operacyjnych PP czy też o zwalczaniu ruchu komunistycznego albo o zachowaniu PP i samego Zamorskiego wobec wydarzeń antysemickich, które miały miejsce choćby we Lwowie, w latach trzydziestych XX w.

Co więcej, mam wrażenie, że Litwiński niekiedy zbyt delikatnie dotyka czasów i wydarzeń, które stanowiły tło życia Kordiana Zamorskiego. Historycy wielokrotnie mają problem $\mathrm{z}$ dobraniem odpowiednich proporcji, aby owe tło uchwycić. W omawianej książce ów kontekst został pokazany marginalnie. Oczywiście nie zarzucam autorowi, że nie rozbudował swojej publikacji do monstrualnych rozmiarów i np. nie opisał historii II wojny światowej. Byłoby to wręcz absurdalne. Niemniej uważam, że pewne rzeczy powinny zostać pokazane. W książce są np. informacje o zatrzymaniu polskich posłów w 1930 r., ale brakuje już fragmentów dotyczących np. zamachu majowego. Ponadto autor zupełnie nie wspomina o śmierci Piłsudskiego. Nie chodzi mi nawet o to, jak Zamorski to wydarzenie postrzegał, ale zapewne PP tę wielką uroczystość pogrzebową zabezpieczała. Chciałbym zatem przeczytać, jak wyglądała praca generała w tamtym okresie. Podobnie dzieje się ze śmiercią Sikorskiego, którego generał dość mocno krytykował. Co więcej, w publikacji na próżno szukać fragmentów dotyczących polskiej konspiracji działającej w okresie II wojny światowej, a autor nie podaje nawet daty zakończenia tego konfliktu. Brakuje również pogłębionych informacji nt. Samodzielnej Brygady Strzelców Karpackich. Przecież Zamorski odpowiadał za Ośrodek Zapasowy tej jednostki. Warto by zatem napisać, co to była za jednostka, jak się w Afryce i na Bliskim Wschodzie znalazła i w jakich walkach uczestniczyła. Z drugiej strony Litwiński napisał choćby o tym, jaka była opinia Zamorskiego nt. ewentualnego wybuchu III wojny światowej i sytuacji Polski po 1945 r.

Właśnie tego typu rzeczy - opinii i spostrzeżeń generała - w niektórych fragmentach brakowało. Oczywiście trudno mówić za źródła, które nie 
istnieją. Tak zapewne było w tym przypadku. Wydaje się jednak, że autor mógł to chociaż skwitować stwierdzeniem, że z powodu braku dokumentacji nie może na ten temat niczego napisać albo spróbować postawić jakieś hipotezy. Zrobił tak np. na s. 281, gdy nawiązał do zamiarów Zamorskiego, który w 1940 r. zastanawiał się nad wysłaniem żony i synów do okupowanego przez Niemców i Sowietów kraju: „Czy Zamorski mógł liczyć, że jego nazwisko, chociażby ze względu na przedwojenne kontakty z Heinrichem Himmlerem czy Kurtem Daluege’em, uratuje rodzinę przez represjami w kraju? Na obecnym etapie badań trudno jednoznacznie o tym zawyrokować, ale nie możemy takiej ewentualności wykluczyć z naszych rozważań”.

Po przeczytaniu książki Roberta Litwińskiego nabrałem wątpliwości co do samego tytułu, a konkretnie do drugiego jego członu - „granatowy generał". Zamorski rozpoczął swoją karierę pod koniec 1918 r., a zakończył $\mathrm{w}$ połowie $1942 \mathrm{r}$. W tym okresie piastował przede wszystkim wiele funkcji wojskowych, łącznie ze stanowiskiem II zastępcy szefa SG WP, a w latach 1935-1939 był komendantem głównym PP. Nie jest to zatem jakiś długi okres, biorąc pod uwagę całokształt jego służbowego życiorysu. Ponadto, jak wynika z omawianej książki. Zamorski czuł się przez większość swojego zawodowego życia żołnierzem. Co więcej, termin "granatowy” bardziej kojarzy się z tzw. „granatową policją", funkcjonującą na obszarze Generalnego Gubernatorstwa pod auspicjami niemieckiego okupanta. W kontekście tego ostatniego zarzutu autor na s. 10 swojej książki wyjaśnia, że w okresie II Rzeczypospolitej termin "granatowy” nie kojarzył się negatywnie. Niemniej uważam, że z dzisiejszej perspektywy określenie to niesie za sobą jednoznaczne niedobre konotacje. Biorąc pod uwagę wszystkie powyżej przedstawione elementy, uważam, że taki tytuł byłby bardziej adekwatny do poprzednika Zamorskiego na stanowisku komendanta głównego PP Janusza Jagryma-Maleszewskiego, który pełnił tę funkcję w latach 1926-1935.

Ponadto w treści książki brakuje mi niekiedy poszerzonych wyjaśnień i rozważań. Na przykład na s. 74 autor pisze, że wiosną 1920 r. Zamorski był szefem Oddziału I Sztabu Dowództwa Etapów Wojsk Polskich na Ukrainie i zastępcą szefa Sztabu Polskiej Ekspozytury Wojskowej działającej przy rządzie Ukraińskiej Republiki Ludowej. Następnie bez żadnego komentarza stwierdza, że na początku sierpnia 1920 r. został oddany do dyspozycji Naczelnego Dowództwa WP. Dlaczego się tak stało? Autor w tekście tego nie wyjaśnia. Być może wynikało to z braku odpowiednich źródeł. Niemniej takie niuanse powinny zostać omówione.

W tekście zdarzają się także niewielkie nieścisłości i błędy. Autor w przypisach biograficznych starał się wyjaśnić życiorysy ogromnej większości osób występujących na łamach książki. Wśród nich byli oficerowie, politycy i żołnierze. Zdarzyło się jednak, że biogramy niektórych osób zostały przez 
Litwińskiego pominięte. Gdy na s. 84 pojawia się w tekście nazwisko płk. Louisa Fauryego, który nie jest powszechnie znany, autor nie wyjaśnia, kim ten człowiek był. Jest to niezrozumiałe, jeżeli na przykład weźmiemy pod uwagę fakt, że na s. 31 można przeczytać biogram gen. Kazimierza Sosnkowskiego, a na kolejnej biogram gen. Władysława Sikorskiego. Oczywiście można uznać, że Faury nie odgrywał jakiejś istotnej roli w życiu Zamorskiego, dlatego jego biogram nie został w publikacji przytoczony. Niemniej podobną do Fauryego rolę w życiorysie "granatowego generała” odegrał Juliusz Malczewski. Jego biogram został jednak sporządzony na s. 20 omawianego dzieła. Ponadto na s. 327 autor napisał, że Zamorski, wyjeżdżając z kraju w 1939 r., pozostawił m.in. „mieszkanie na al. Schucha”. Powinno być ul. Szucha. Być może jest to jednak zwykły błąd redakcyjny.

W konkluzji chciałbym zaznaczyć, że w mojej ocenie praca Roberta Litwińskiego dotycząca gen. Kordiana Józefa Zamorskiego jest książką ważną i potrzebną. Przede wszystkim wypełnia lukę w historiografii. Oparta jest również na solidnej kwerendzie źródłowej. Wątpliwości nie budzi również większość wniosków wyciąganych przez autora. Co więcej, Litwiński bardzo sprawnie operuje językiem polskim, przez co jego opracowanie czyta się bardzo dobrze. Ponadto autor ubogacił treść publikacji o dość pokaźny materiał ilustracyjny. Oczywiście - co wykazałem w niniejszej recenzji - są także elementy dyskusyjne. Nie wpływają one jednak na merytoryczną jakość pracy. Wydaje mi się zatem, że warto na książkę Litwińskiego spojrzeć życzliwym okiem.

Paweł Sztama

DOI: 10.32089/WBH.phw.2019.2(268).0009 orcid.org/0000-0002-1268-0432

\section{Some remarks on Robert Litwiński’s book Kordian Józef Zamorski - the „blue” general}

Biographical research is one of the most difficult historiographical forms ${ }^{1}$, or perhaps even the most challenging one. This is mainly due to methodological and source-related issues. A historian who prepares a biography must not only investigate thoroughly into the life of the protagonist of the book, but should also get significant insight into the times when

\footnotetext{
https://www.polskieradio.pl/8/3664/Artykul/1210511,Profesor-Antoni-Dudek-napisalem -biografie-potwora-bo-mnie-zainteresowal (accessed on 25.02.2019).
} 